\title{
An Anglo-Irish Radical in the Late Georgian Metropolis: Peter Finnerty and the Politics of Contempt
}

\section{Jonathan Jeffrey Wright}

\begin{abstract}
This article focuses on the Irish-born metropolitan radical and parliamentary journalist Peter Finnerty, exploring, in particular, the distinctive nature of his political engagement. Chiefly remembered as a friend of William Hazlitt and an implacable opponent of Lord Castlereagh, Finnerty was an influential figure in his own right, who moved between a range of social and political spaces. Framing him as an unrepentant Irish radical, indifferent to the coercive power of authority, this article will examine Finnerty's involvement in a range of scandals, controversies, and causes célèbres, and will highlight the ways in which he succeeded, through enacting a contempt for authority, in subverting both the courtroom and Parliament itself.
\end{abstract}

\section{A}

s scholars of eighteenth-century Irish radicalism have long been aware, the defeat of the United Irish rebellion in the summer of 1798 did not mark the end of Irish radical agitation. In Ireland, reports of disorder and disaffection continued to trickle in to Dublin Castle until well into the early nineteenth century, and farther afield, exiled radicals remained politically engaged. A coterie of prominent United Irishmen is, for instance, known to have remained active in Paris, where they laid the groundwork for Emmet's rising in $1803 .^{1}$ Similarly, United Irish émigrés and deportees carried their disaffection with them to Australia and the United States, spreading what Michael Durey has characterized as "an Irish revolutionary contagion."2 Indeed, as a series of recent studies have demonstrated, United Irish exiles played a prominent role in the political life of the early American Republic, particularly in Philadelphia, where they helped shape postrevolutionary party politics and "contributed to the re-invention of America." 3 But one

Jonathan Jeffrey Wright is a research fellow at Queen's University, Belfast. He would like to thank audiences at the Ireland, America and the Worlds of Matthew Carey conference at Trinity College Dublin in November 2011 and the Glasgow Caledonian University 2012-13 history seminar series. Thanks are also due to Prof. Sean Connolly, Dr. Sarah Roddy, Dr. S. Karly Kehoe, Dr. Carl Griffin, and reviewers for the Journal of British Studies for their insightful comments.

${ }^{1}$ Marianne Elliott, Partners in Revolution: The United Irishmen and France (New Haven, CT, 1982), 282-322.

${ }^{2}$ Michael Durey, "Marquess Cornwallis and the Fate of Irish Rebel Prisoners in the Aftermath of the 1798 Rebellion," in Revolution, Counter-Revolution and Union: Ireland in the 1790s, ed. Jim Smyth (Cambridge, 2000), 129.

${ }^{3}$ Maurice J. Bric, Ireland, Philadelphia and the Re-Invention of America, 1760-1800 (Dublin, 2008), xii, xviii. See also Michael Durey, Transatlantic Radicals and the Early American Republic (Lawrence, KS, 
need not cross the Atlantic to trace the continuing activities of Irish radicals: they played an equally important role in England.

Highlighted many years ago by E. P. Thompson, the interaction of Irish and English radicals in the late eighteenth and early nineteenth centuries received some attention in the 1980s, most notably in the groundbreaking scholarship of Marianne Elliott, but also in the work of Roger Wells and Iain McCalman. ${ }^{4}$ In recent years, however, these interactions have been somewhat neglected; indeed, the AngloIrish radical dimension was largely absent from the scholarship produced to mark the 1998 bicentenary of the 1798 rebellion. ${ }^{5}$ Added to this recent neglect, the limited body of work that does address Anglo-Irish radical interactions during the age of revolution and reform has tended to focus either on the 1790s or on the 1820s and 1830s, overlooking the 1800s and 1810s. ${ }^{6}$ Writing in the early 1980s, Wells neatly highlighted this neglect. "Every popular political movement after 1800 had an Anglo-Irish dimension," he asserted. "This essential dimension has been reflected in historical writing on the Emancipation crisis in the late 1820s, the constitutional crisis surrounding the Reform Bill of 1831-2, and above all the Chartist era; it has been ignored during the 1800-20 period."7 On the whole, the complaint remains a valid one. Thus, the ensuing discussion will seek to reestablish the significance of Anglo-Irish radical interactions, taking their story into the 1800s and 1810s by tracing the picaresque career of the little-known journalist and political agitator Peter Finnerty.

At the outset, it is important to state that Finnerty, if little known, is not unknown. Twice tried for libel, he was notorious in his own day and appears as a minor character, albeit a colorful one, in studies of other, "greater" men-men such as William Hazlitt or Lord Castlereagh. ${ }^{8}$ In addition, he makes sporadic appearances

1997); David A. Wilson, United Irishmen, United States: Immigrant Radicals in the Early Republic (Ithaca, 1998).

${ }^{4}$ E. P. Thompson, The Making of the English Working Class (Harmondsworth, 1968); Marianne Elliott, "The 'Despard Conspiracy' Reconsidered," Past \& Present 75 (May 1977): 46-61; Marianne Elliott, "Irish Republicanism in England: The First Phase, 1797-9," in Penal Era and Golden Age: Essays in Irish History, 1690-1800, ed. Thomas Bartlett and D. W. Hayton (Belfast, 1979), 204-21; Elliott, Partners in Revolution; Roger Wells, Insurrection: The British Experience, 1795-1803 (Gloucester, 1983); Iain McCalman, "Erin go Bragh': The Irish in British Popular Radicalism, c. 1790-1840," in Irish-Australian Studies: Papers Delivered at the Fifth Irish-Australian Conference, ed. Oliver MacDonagh and W. F. Mandle (Canberra, 1989), 168-84.

${ }^{5}$ Significantly, 1798: A Bicentenary Perspective, ed. Thomas Bartlett, David Dickson, Dáire Keogh, and Kevin Whelan (Dublin, 2003), the highly impressive collection of essays that emerged from a major conference marking the two hundredth anniversary of the 1798 rebellion, contains no sustained discussion of Irish/English radical links.

"Dorothy Thompson, "Ireland and the Irish in English Radicalism Before 1850," in The Chartist Experience: Studies in Working-Class Radicalism and Culture, 1830-60, ed. James Epstein and Dorothy Thompson (London, 1982), 120-51.

7 Wells, Insurrection, 264.

${ }^{8}$ Stanley Jones, Hazlitt: A Life -From Winterslow to Frith Street (Oxford, 1991), 26, 74-75; A. C. Grayling, The Quarrel of the Age: The Life and Times of William Hazlitt (London, 2001), 153-54; Duncan Wu, William Hazlitt: The First Modern Man (Oxford, 2008), 145, 150, 164, 225, 245, 411; H. M. Hyde, The Rise of Castlereagh (London, 1933), 423-28; Ione Leigh, Castlereagh (London, 1951), 221-22; H. M. Hyde, The Strange Death of Lord Castlereagh (London, 1959), 151-53; John Bew, Castlereagh: Enlightenment, War and Tyranny (London, 2011), 112, 278-79. 
in literature relating to the United Irish movement, the freedom (or lack thereof) of the press in late Georgian Britain, and London radicalism. ${ }^{9}$ Most notably, he occupies a prominent place in McCalman's important, if largely overlooked, 1989 essay, "Erin go Bragh': The Irish in British Popular Radicalism, c. 1790-1840.” However, while this piece established Finnerty as an important figure in post -1798 metropolitan radicalism, detailing some of the controversies in which he participated, a full account of his life and career lay beyond its scope. Thus, Finnerty remains, as Malcolm Chase has described him, "an important figure in Anglo-Irish radicalism, of whom a study is wanting." 10

Although this discussion cannot hope to provide the comprehensive treatment Finnerty deserves, it can build upon existing work to provide a fuller account of his life-an account that attends to both its Irish and its English dimensions and sheds light on the interconnected milieux he inhabited. Invariably, this invites the thorny question as to how representative a figure Finnerty was. In the end, of course, no historical personality can be said to represent anything other than a single lived experience, and it cannot be denied that Finnerty was a singular character. Yet it does not follow that the trajectory of his life story was unique, or that his biography is of limited interest - quite the reverse. Biographical case studies provide us, in Paul A. Pickering's words, with a "lens through which to explore an endlessly complex world." ${ }^{11}$ Like microhistory, a genre with which it has much in common, the biographical case study can offer new perspectives on historical processes and phenomena, enabling us, in the language of sociology, to explore cultures and societies "from the individual 'upwards,' rather than from the social structure 'downwards."'12

Finnerty might, then, have been a singular figure, but he nevertheless provides us with a means to explore the world of early nineteenth-century metropolitan radicalism. In particular, his is a story that reveals the variety of social and political spaces that could make up a radical's world, while also foregrounding the importance of

\footnotetext{
9 Elliott, Partners in Revolution, 288, 296, 345; Nancy J. Curtin, The United Irishmen: Popular Politics in Ulster and Dublin, 1791-1798 (Oxford, 1998), 213, 223; Arthur Aspinall, Politics and the Press, c. 17801850 (London, 1949), 36, 62; Brian Inglis, The Freedom of the Press in Ireland, 1784-1841 (London, 1954), 100-04; J. Ann Hone, For the Cause of Truth: Radicalism in London, 1796-1821 (Oxford, 1982), 54, 125, 134, 141, 147, 152, 169, 173, 182, 196-99, 201, 216, 232, 249, 329, 356; Iain McCalman, Radical Underworld: Prophets, Revolutionaries and Pornographers in London, 1795-1840 (Cambridge, 1988), 16-17, 89; Peter Spence, The Birth of Romantic Radicalism: War, Popular Politics, and English Radical Reformism, 1800-1815 (Aldershot, 1996), 39, 96, 116-17, 165-67, 171, 174, 199, 200.

${ }^{10}$ Malcolm Chase, The People's Farm: English Radical Agrarianism, 1775-1840 (Oxford, 1988), 97n39.

${ }^{11}$ Paul A. Pickering, "Introduction: History as Innovation: The Work of Iain McCalman," in Unrespectable Radicals? Popular Politics in the Age of Reform, ed. Michael T. Davis and Paul A. Pickering (Aldershot, 2008), 1.

${ }^{12}$ Michael Rustin, "Reflections on the Biographical Turn in Social Science," in The Turn to Biographical Methods in Social Science: Comparative Issues and Examples, ed. Prue Chamberlayne, Joanna Bornat, and Tom Wengraf (London, 2000), 45. No mention of microhistory would be complete without references to the two classics of the genre: Carlo Ginzburg, The Cheese and the Worms: The Cosmos of a SixteenthCentury Miller (Baltimore, 1980), and Natalie Zemon Davis, The Return of Martin Guerre (Cambridge, MA, 1983). For broader reflections see Carlo Ginzburg, "Microhistory: Two or Three Things That I Know about It," Critical Inquiry 20, no. 1 (Autumn 1993): 10-35; Jill Lepore, "Historians Who Love Too Much: Reflections on Microhistory and Biography," Journal of American History 88, no. 1 (June 2001): 129-44.
} 
performance in radical politics. As James Epstein and David Karr have recently demonstrated, radical performance was an important form of expression in the repressive context of the 1790s. Attuned to the ways in which their behavior was interpreted, radicals used gesture and performance pointedly, overplaying their roles, "testing limits," and "exploring expressive boundaries." Such activity was, however, by no means unique to the 1790s: posture and performance were exploited with equal value in the 1800s and 1810s, and not least by Finnerty, who regularly enacted his contempt for the authority of the state.

While proceeding chronologically, the ensuing discussion will address four discrete themes within the broader context of Finnerty's life story. The first section will reflect on his politicization as a young man; the second section will locate him within the context of early nineteenth-century London, identifying the different spaces he inhabited and roles he performed; the third section will focus on his trial for seditious libel in 1811, reflecting on the ways in which he used the court as a stage on which to perform the politics of contempt and subvert authority; and the fourth section will address his later years, paying particular attention to his character as it was revealed in the judgment of his contemporaries. As will become clear, Finnerty was an unrepentant Irish radical whose indifference to the coercive power of authority enabled him to acquire a certain celebrity in late Georgian London. Reconstructing his career and exploring the overlapping metropolitan life-spaces he inhabited will not only offer a sense of Finnerty the man but also reveal a diversely populated political world in which the boundaries between repute and disrepute were not always clearly defined.

Details concerning Finnerty's early life are regrettably scarce. Although believed to have been born in Loughrea, County Galway, this cannot be said for sure, nor can his date of birth be given. ${ }^{14}$ When he died in 1822, an obituary in the Gentleman's Magazine gave Finnerty's age as fifty-six, suggesting he was born in $1766 .{ }^{15}$ By contrast, an article published in Leigh Hunt's Examiner in 1811 claimed that Finnerty was aged twenty in 1798, suggesting he was born, rather later, in $1778 .{ }^{16}$ A third source, an obituary that appeared in the Morning Chronicle, whose editor knew Finnerty well, gave no age at death but stressed that he had been a mere youth when he first became politically active in Dublin during the 1790s; so young, indeed, that he was "scarcely of age." 17 Given this, the later year of birth, deduced from the Examiner, seems more likely, but the precise date remains unknown. What is known, however, is that Finnerty was the son of a merchant or tradesman of "slender means" and that he was, at a young age, "cast upon his fortunes" in Dublin,

\footnotetext{
${ }^{13}$ James Epstein and David Karr, "Playing at Revolution: British 'Jacobin' Performance," Journal of Modern History 79, no. 3 (September 2007): 507, 520.

${ }^{14}$ It is known that Finnerty's father was a tradesman in Loughrea during the 1790s, but no baptismal record has yet been located and it does not follow that Finnerty was born there. Morning Chronicle, 15 May 1822; David Ryan, "Dissafection and Rebellious Conspiracy in the Loughrea Area, 1791-1803," in The District of Loughrea, vol. I, History, 1791-1918, ed. Joseph Forde, Christina Cassidy, Paul Manzor, and David Ryan (Loughrea, 2003), 20; Dictionary of Irish Biography: From the Earliest Times to the Year 2002, ed. James McGuire and James Quinn, 9 vols. (Cambridge, 2009), 3:793.

${ }^{15}$ Gentleman's Magazine, 92 (1822): 644.

${ }^{16}$ Examiner, 24 February 1811.

${ }^{17}$ Morning Chronicle, 15 May 1822.
} 
where he served as an apprentice printer with the proprietor of the Hibernian Telegraph, William Corbet. ${ }^{18}$

That Finnerty trained as a printer was significant, for in so doing he entered a hazardous milieu. During the 1790s, Dublin Castle was anxiously engaged in buying up newspapers and cultivating informers among the ranks of the Dublin pressmen as it sought, in Thomas Bartlett's words, to "control the dissemination of information. ${ }^{19}$ In such circumstances, radicals rubbed shoulders with government agents, and things were not always as they seemed. But while there were dangers inherent in a career as a Dublin pressman, Finnerty appears to have been little concerned. Indeed, as the 1790s progressed, he moved further into this world, forming contacts with prominent radicals, such as the aristocratic United Irishman Arthur O'Connor. Thanks no doubt to these connections, Finnerty was named as proprietor when the Dublin United Irishmen established their newspaper, The Press, in September 1797.20 At this stage a mere nineteen years of age (assuming he was born in 1778, rather than 1766), Finnerty served as proprietor in a titular sense only. He was, as the perceptive government informer Francis Higgins put it, "a young man of straw," who provided cover for the more prominent radicalsmen such as O'Connor-who were behind the paper. ${ }^{21}$ The expediency of this measure quickly became apparent. No sooner had The Press appeared than Dublin Castle sought to suppress it. Those selling and buying the paper were harassed, underhand attempts were made to insert defamatory material, and little more than a month after its first issue had appeared, Finnerty was arrested and charged with libel. ${ }^{22}$

The libel charge related to a letter published in The Press that detailed irregularities that had occurred during the trial and execution of the County Antrim United Irishman William Orr. ${ }^{23}$ The case went to court on 22 December 1797, and Finnerty, who refused to reveal the identity of the letter's author, was found guilty. ${ }^{24}$ In a

\footnotetext{
${ }^{18}$ Higgins to Cooke, 21 September 1797, in Revolutionary Dublin, 1795-1801: The Letters of Francis Higgins to Dublin Castle, ed. Thomas Bartlett (Dublin, 2004), 184; Morning Chronicle, 15 May 1822; Helen Maher, Galway Authors: A Contribution Towards a Biographical and Bibliographical Index, with an Essay on the History and Literature of Galway (Galway, 1976), 44; Oxford Dictionary of National Biography, ed. H. C. G. Matthew and Brian Harrison, 60 vols. (Oxford, 2004), 19:623; McGuire and Quinn, Dictionary of Irish Biography, 3:793; Aspinall, Politics and the Press, 113n2; Inglis, Freedom of the Press, 100.

${ }^{19}$ Finnerty's employer, William Corbett, was one such informer. Thomas Bartlett, introduction to Bartlett, Revolutionary Dublin, 18; Inglis, Freedom of the Press, 62-64.

${ }^{20}$ Fraser's Magazine 65 (1862): 171; Inglis, Freedom of the Press, 100. O'Connor awaits an authoritative biographical treatment, but see Frank MacDermot, "Arthur O'Connor," Irish Historical Studies 15, no. 57 (March 1966): 48-69; Jane Hayter Hames, Arthur O'Connor, United Irishman (Cork, 2001); Clifford D. Conner, Arthur O'Connor: The Most Important Irish Revolutionary You May Never Have Heard Of (Bloomington, 2009).

${ }^{21}$ Higgins to Cooke, 21 September 1797, in Bartlett, Revolutionary Dublin, 184; Curtin, United Irishmen, 213.

${ }^{22}$ Inglis, Freedom of the Press, 100-01.

${ }^{23}$ [Anon.], Trial of Mr Peter Finerty [sic], Late Printer of The Press, for a Libel Against His Excellency Earl Camden, Lord Lieutenant of Ireland, in a Letter Signed Marcus, in that Paper (Dublin, 1798), 14-17. For Orr, see W. E. H. Lecky, A History of Ireland in the Eighteenth Century, new edition, 5 vols. (London, 1892), 4:103-16; Francis Joseph Bigger, The Northern Leaders of '98 (No. 1) William Orr (Belfast, 1906; repr., 1998); Curtin, United Irishmen, 85-87.

${ }^{24}$ Signed "Marcus," the letter has been attributed to Deane Swift, son of the Dublin barrister Theophilus Swift. Thomas MacNeven, The Lives and Trials of Archibald Hamilton Rowan, the Rev. William Jackson, the Defenders, William Orr, Peter Finnerty, and Other Eminent Irishmen (Dublin, 1846), 494.
} 
technical sense this was a victory for Dublin Castle, but in real terms it was a defeat. For one thing, it had little impact on The Press itself. While one issue was missed during the course of the trial, O'Connor subsequently assumed the paper's proprietorship and thereafter it went from strength to strength, its circulation rising, as Nancy Curtin has noted, "from an impressive 3,000 to an astonishing 6,000." It was not, indeed, until the following March that the government succeeded, via the rather more direct means of destroying its presses, in quashing the paper. ${ }^{25}$ More broadly, in prosecuting Finnerty Dublin Castle had played into the hands of the radicals. Writing to his sister, Martha McTier, in September 1797, William Drennan, a founding member of the United Irishmen, who had withdrawn from radical agitation following his own trial for seditious libel in 1794, predicted that The Press would be "put down"; "perhaps this is the great reason for putting it up," he noted sagely, "to exhibit the impracticability of writing freely at present, in public print." 26 That The Press's supporters had themselves nicknamed it the "Newgate Paper," resolving to "carry it on even though the printer etc. etc. should be in Newgate, and suffering every severity in support of their cause," suggests that Drennan's analysis was close to the mark, and the accuracy of his analysis is further underscored by the way in which Finnerty's defense was handled. ${ }^{27}$ John Philpot Curran, who had earlier defended Orr, was appointed as Finnerty's counsel. But rather than addressing himself to the particularities of Finnerty's alleged offense, Curran used the trial to revisit the earlier case, decrying the government's treatment of Orr. ${ }^{28}$ Simply put, the United Irishmen employed Finnerty's trial for the purposes of propaganda, using it to demonstrate resolve and scratch old wounds. That this was scarcely calculated to secure Finnerty's release was not the point: an imprisoned newspaper proprietor, whose treatment illustrated the hostility and partiality of the Irish administration, was of altogether more use than an exonerated one, whose freedom demonstrated the fairness of the Irish courts.

A further opportunity to demonstrate resolve and enact defiance was provided when the sentence was served. Writing on the day of the trial, the informer Francis Higgins advised Edward Cooke, undersecretary at Dublin Castle, that Finnerty's conviction would "if properly punished . . . be of infinite utility." 29 However,

${ }^{25}$ Curtin, United Irishmen, 223.

${ }^{26}$ Drennan to McTier, 29 September 1797, in The Drennan McTier Letters, ed. Jean Agew, 3 vols. (Dublin, 1998-99), 2:339; Curtin, United Irishmen, 213. For Drennan's libel trial, see The Trial of William Drennan, ed. John Larkin (Dublin, 1991).

${ }^{27}$ Higgins to Cooke, 21 September 1797, in Bartlett, Revolutionary Dublin, 184.

${ }^{28}$ Anthologized and reprinted numerous times during the course of the nineteenth century, Curran's address on this occasion was arguably the most significant of the high-flown orations on which his subsequent reputation as a champion of Irish liberty was based. Lecky judged it to be "the best statement of the case for Orr," while Curran's biographer, Charles Phillips, asserted that it contained passages "unsurpassed in our language." [Anon.], Trial of Mr Peter Finerty, 34-55; Vicesimus Knox, ed., Elegant Extracts: Or Useful and Entertaining Passages in Prose (London, 1824), 433-34; [A member of the Bar], Irish Eloquence: The Speeches of the Celebrated Irish Orators Philips, Curran and Grattan to which is Added the Powerful Appeal of Robert Emmet, at the Close of His Trial for High Treason (Boston, 1857), 332-61; Jonathan Barber, The Elocutionist, Consisting of Declamations and Readings, in Prose and Poetry; For the Use of College and Schools, 2nd ed. (New Haven, CT, 1836), 51-53; MacNeven, The Lives and Trials of . . Eminent Irishmen, 481-545; Charles Phillips, Curran and His Contemporaries, 5th ed. (London, 1857), 174; Lecky, Ireland, 4:115; Bigger, William Orr, 76.

${ }^{29}$ Higgins to Cooke, 22 December 1797, in Bartlett, Revolutionary Dublin, 206. 
when passing sentence, the judge miscalculated: in addition to fining Finnerty and sentencing him to two years imprisonment, he condemned him to stand in the pillory for an hour and, in so doing, unwittingly provided Dublin's radicals with an opportunity to display their strength. ${ }^{30}$ When Finnerty was taken to the pillory, a large and sympathetic crowd gathered. Moreover, in an economical piece of political street theater, which effectively undermined what was intended as a humiliating punishment, he was accompanied by a group of well-known radicals, including Lord Edward Fitzgerald, Oliver Bond, Henry Jackson, William Sampson, and Arthur O'Connor. This alone served to subvert and undermine the punishment, but O'Connor added a comic dimension to proceedings by holding an umbrella over Finnerty's head. ${ }^{31}$

The creation of spectacle and display of contempt for authority were later to become regular and defining characteristics of Finnerty's political activities. At this point, though, we might inquire in more general terms as to the nature of his political engagement as a youth. While his centrality to the performance described is readily apparent-he was, after all, in the pillory-questions may nevertheless be raised regarding the agency, or lack thereof, that Finnerty exercised in the affair. Given his youth, and the fact that he was registered as the proprietor of The Press in order to protect its real proprietors, the issue of consent arises: was Finnerty a passive participant, employed-perhaps even exploited-by more senior radicals? A brief biographical sketch, penned by William Hazlitt several years after Finnerty's death, would suggest not. Upon initially arriving in Dublin, Hazlitt related, Finnerty had secured employment with a furniture upholsterer who found him "too fond of reading political pamphlets and attending public meetings" to be of use, and quickly "determined to get rid of him," recommending him to a friend, a printer, "as a smart fellow, who would make himself useful." This printer found his young charge equally unsuitable: "He was not long in the new concern, until his master, on entering the composing-room one morning, discovered FINNERTY mounted on one of the frames, haranguing the men on liberty and equality." 32 As depicted here, Finnerty appears to have been an ardently political youth, fired by the ideals of liberty and equality. To confirm the accuracy of this representation, we need look no further than his conduct during his trial. Rather than displaying remorse, when called upon to receive sentence, Finnerty taunted the judge, delivering a lengthy speech, wherein he complained of the attempts that had been made to recruit him as an informer and declared that he had "uniformly acted from that feeling of patriotism, which I hope it is not yet considered criminal to indulge." 33 Likewise, when released from the pillory, he struck a defiant note in a brief address to the assembled crowd: "[Y] ou see how cheerfully I can suffer," he proclaimed, "I can suffer any thing provided it promotes the liberty of my country." 34 Hitherto respectfully silent, the crowd responded to this display of defiance with cheers and

${ }^{30}$ [Anon.], Trial of $\mathrm{Mr}$ Peter Finerty, 62.

${ }^{31}$ Higgins to Cooke, 3 January 1798, in Bartlett, Revolutionary Dublin, 210; Phillips, Curran and His Contemporaries, 172.

${ }^{32}$ William Hazlitt, "Peter Finnerty," in New Writings of William Hazlitt, ed. Duncan Wu, 2 vols. (Oxford, 2007), 2:224.

${ }^{33}$ [Anon.], Trial of Mr Peter Finerty, 59-60.

34 Ibid., 62. 
applause, provoking a scuffle with the attendant soldiers during which, Edward Cooke laconically observed, "a few toes were trod on."35

At the very least, then, Finnerty knew how to act the part of the defiant radical. Given this, and bearing in mind his subsequent career as a radical agitator, it seems fair to conclude that the experience of imprisonment, rather than denting his resolve, served only to alienate him further from the government. Certainly, it appears to have marked him deeply: writing after Finnerty's death, one associate recalled that Finnerty had "often described" his imprisonment, when "too frequently the guest of the breakfast-table . . . was hurried forth to sudden execution." 36 Such descriptions were doubtless vivid, but whether or not they were accurate is another matter. While there were, to be sure, many executions in Ireland during the course of 1798, those executed were typically suspected rebels captured in the run-up to, or during the course of, the United Irish rebellion itself, not those who had earlier been tried and imprisoned-whether for treason or for "ordinary" criminal offenses-by due legal process. ${ }^{37}$ In this light, Finnerty's claim to have witnessed fellow prisoners "hurried forth" to execution rings false. But whatever might be said about the accuracy of his recollections, the more important point concerns Finnerty's utilization of them: he "often described" his imprisonment, constructing a narrative that emphasized his firsthand experience of the excesses of authority. ${ }^{38}$ Whether accurate or not, Finnerty's memory of government repression was to become central to his understanding of his own life story, and he was to pursue a longstanding vendetta against Lord Castlereagh, the man he believed to be responsible, above all others, for the violence meted out in Ireland in 1798. ${ }^{39}$

Upon his release from prison, Finnerty found "he could not obtain any establishment or subsistence in Ireland” and resolved to quit Dublin for London. ${ }^{40}$ Doubtless influenced by reports that he was in contact with known United Irishmen from the Loughrea area, Castlereagh sought to prevent him from doing so. ${ }^{41}$ This further

${ }^{35}$ Mary Pollard, A Dictionary of Members of the Dublin Book Trade, 1550-1800: Based on the Records of the Guild of St Luke the Evangelist, Dublin (London, 2000), 209.

${ }^{36}$ Morning Chronicle, 15 May 1822.

${ }^{37}$ For the operation of martial law in Ireland in 1798, see Durey, "Marquess Cornwallis and the Fate of Irish Rebel Prisoners," and Thomas Bartlett, "Clemency and Compensation: The Treatment of Defeated Rebels and Suffering Loyalists After the 1798 Rebellion," in Smyth, Revolution, Counter-Revolution and Union, 99-127 (esp. 105-18), 128-45. Military violence and executions in Dublin are detailed in Ruán O'Donnell, Robert Emmet and the Rebellion of 1798 (Dublin 2003), 80-121.

${ }^{38}$ Another account, published in the Examiner in 1811, claimed that Finnerty had been "confined in a gaol-room sixteen feet by nine with fourteen other persons, some . . convicted of capital offences.” Most likely influenced by Finnerty's own claims, this account does not tally with the irate missive, penned on 3 January 1798, in which the informer Francis Higgins complained that Sherriff Archer "sent to know if Finnerty was made easy and comfortable or had he any cause of complaint." Examiner, 24 February 1811; Higgins to Cooke, 3 January 1798, in Bartlett, Revolutionary Dublin, 210.

${ }^{39}$ For McCalman, "Castlereagh's supposed encouragement of brutal reprisals against the rebels of '98 . . . became Finnerty's idée fixe." McCalman, "Erin go Bragh," 178.

${ }^{40}$ [Anon.], Case of Peter Finnerty, Including a Full Report of All the Proceedings which Took Place in the Court of King's Bench upon the Subject . . . to which is Annexed, an Abstract of the Case of Colonel Draper, upon which Precedent Mr Finnerty Professed to Act (London, 1811), xxvii.

${ }^{41}$ Inglis, Freedom of the Press, 104; Ryan, "Dissafection and Rebellious Conspiracy in the Loughrea Area," 20-21. 
alienated Finnerty but did not, in the long term, arrest his plans: he eventually reached London-disguised, according to one possibly dubious account, as a sailor-and set about establishing himself in a variety of discrete, but overlapping, metropolitan spaces. ${ }^{42}$ As distinct from "places," or "contexts," "spaces" is used here as a term that foregrounds the importance of location in shaping and informing action. Profitably employed by historians of science who have explored the varied ways in which locations, whether discursive or institutional, have informed the construction of knowledge, analyses sensitive to the possibilities inherent in particular spaces are by no means irrelevant to the study of radicalism. ${ }^{43}$ James Epstein, for instance, has suggested that "we take seriously 'the spatial' as critical for understanding how political meanings are ordered, lives are lived and how alternative social worlds are imagined." 44 Likewise, Christina Parolin has attempted to delineate the numerous spaces accessed and exploited by metropolitan radicals over the long period 1790-1845. ${ }^{45}$ Ranging from the prison cells of Newgate and Coldbath Fields to more "public" locations, such as the Crown and Anchor tavern, these spaces constituted more than a mere backdrop to radical activity. Rather, as Parolin argues, they facilitated political engagement and "provided a generation of men and women excluded from the formal machinery of politics with a voice in the public sphere." 46 What, then, were Finnerty's metropolitan spaces, and in what ways did he capitalize upon their potential?

Perhaps the most significant of Finnerty's metropolitan spaces-certainly the most visible-was that occupied by Fleet Street's parliamentary hacks. Finnerty arrived in London equipped with a letter of introduction to James Perry, editor of the Morning Chronicle, and he quickly secured employment as a parliamentary reporter. ${ }^{47} \mathrm{He}$ was a natural fit. London's parliamentary press pack was "a tough and cynical bunch," and was, moreover, distinctly Hibernian in complexion. ${ }^{48}$ Later in the century, James Grant, himself a parliamentary reporter of some renown, estimated that three-quarters of the parliamentary reporters active in London in the late eighteenth and early nineteenth centuries were Irish, attributing this to the activities of Richard Brinsley Sheridan. In Grant's telling, Sheridan encouraged Irish hacks to settle in London and used his influence to secure positions for them in the hope that they would, when reporting, do "all the greater justice to his own speeches." 49 Whether this was true or not is moot, but the Irish character of the London press was widely known. Indeed, as McCalman has noted, the Birmingham Monthly Argus later went so far as to write of the existence of "a virtual pro-Catholic press lobby

${ }^{42}$ Examiner, 24 February 1811.

${ }^{43}$ For a classic statement of the importance of space in the construction of knowledge, see David N. Livingstone, Putting Science in Its Place: Geographies of Scientific Knowledge (Chicago, 2003).

44 James Epstein, "Spatial Practices/Democratic Vistas," Social History 24, no. 3 (October 1999): 297.

${ }^{45}$ Christina Parolin, Radical Spaces: Venues of Popular Politics in London, 1790-c. 1845 (Canberra, 2010).

See also David Featherstone, "Review Article: The Spaces of Politics of the London Corresponding Society," Journal of Historical Geography 30, no. 4 (October 2004): 783-91.

${ }^{46}$ Parolin, Radical Spaces, 15.

${ }^{47}$ Fraser's Magazine 65 (1862): 172; Ivon Asquith, "James Perry and the Morning Chronicle, 17901821 " (PhD diss., London University, 1973), 105.

${ }^{48}$ Grayling, The Quarrel of the Age, 153.

49 James Grant, The Newspaper Press; its Origins Progress and Present Position, 2 vols. (London, 1871), $2: 220$. 
which helped to influence the attainment of Catholic emancipation in 1829." $" 50$ While doubtless exaggerated, such claims nevertheless point to a contemporary perception that the Irish pressmen were highly influential and, at the very least, illustrate their involvement in shaping British political culture.

Particularly prominent in this Irish community was Mark Supple, a mainstay of the Morning Chronicle, with whom Finnerty formed a fast friendship. A garrulous, "bigboned" wit, Supple had left Ireland in the 1780s and had, by the time of Finnerty's arrival in the capital, secured a reputation as the "licensed wag" of the parliamentary reporters' gallery. ${ }^{51}$ That the two should have become friends was scarcely surprising. Aside from the fact that they were both Irish, both were heavy drinkers-biographical reminiscences invariably place them carousing in Bellamy's chophouse or the Cider Cellars, establishments frequented by the London press-and both shared a mischievous sense of humor. ${ }^{22}$ Supple had famously reduced the House of Commons to roars of laughter-even Pitt was seen to shake with mirth-by calling loudly, during a particularly tedious session, for "A song from $\mathrm{Mr}$. Speaker."53 Similarly, Finnerty was the source of a story relating to a trick he played on a fellow journalist who had the misfortune to fall asleep in the reporters' gallery. Upon waking, the hapless reporter inquired if he had missed anything, whereupon Finnerty informed him that William Wilberforce had delivered a speech advocating the cultivation of potatoes, during which he had observed that:

[p]otatoes made men healthy, vigorous, and active; but, what is still more in their favour, they make men tall: more especially was he led to say so, as being rather under the common size, and he must lament that his guardians had not fostered him under that genial vegetable. ${ }^{54}$

This was nonsense, but it duly appeared in print, and the following day an exasperated Wilberforce informed Parliament that he had been "grossly misrepresented." 55

Such stories may be interpreted in a number of ways. On one level, they serve to illustrate the mischievous, prankish wit of Supple, Finnerty, and the reporters of the early nineteenth century. But, more significantly, they reveal a marked irreverence and contempt for the pretensions of politicians and the dignity of Parliament. That Finnerty was to retain this irreverence for the duration of his career as a reporter is readily illustrated by the furore he caused in June 1819 when caught, in contravention of parliamentary rules, taking notes while sitting in the front row of the strangers' gallery. When asked by an official to desist, Finnerty responded brusquely: raising

${ }^{50}$ McCalman, "Erin go Bragh,” 174.

${ }^{51}$ Pryse Lockhart Gordon, Personal Memoirs; or Reminiscences of Men and Manners at Home and Abroad During the Last Half Century, 2 vols. (London, 1830), 1:297; William Jerdan, The Autobiography of William Jerdan . . . with His Literary, Political, and Social Reminiscences and Correspondence During the Last Fifty Years, 4 vols. (London, 1852-53), 1:87; Alexander Andrews, The History of British Journalism; from the Foundation of the Newspaper Press in England, to the Repeal of the Stamp Act in 1855, with Sketches of Press Celebrities, 2 vols. (London, 1859), 2:31.

${ }^{52}$ McCalman, "Erin go Bragh," 174.

${ }^{53}$ Grant, The Newspaper Press, 2:222-24; Andrews, The History of British Journalism, 2:31-32.

54 "Wilberforce, Speech to the House of Commons," 7 March 1800, Parliamentary Debates, Commons, lst ser., vol. 34 (1798-1800), col. 1550; Grant, The Newspaper Press, 2:226.

55 John Pollock, Wilberforce (London, 1977), 171-72. 
his notebook higher, he advised the official to "[g]o to Hell." This was reported to the speaker, who brought Finnerty before the bar of the house. There, he "denied having used the expression imputed to him," despite the fact that the exchange had been widely overheard. Further investigation ensued, and Finnerty eventually issued a half-hearted and demonstrably insincere apology. "At the time the circumstance occurred," he explained, "my mind was engaged in the most intense application to the individual who was then addressing the House.... At this conjuncture I was interrupted, and God knows what might have escaped me!" Doubtless wishing to avoid a cause célèbre, the House accepted this, reprimanding Finnerty rather than committing him to Newgate. Scandal was avoided, but the affair had done little to augment the dignity of Parliament. ${ }^{56}$

The unruly ranks of the parliamentary press pack thus constitute one important space in which Finnerty must be located, a space that not only nurtured his contempt for authority but also provided him with novel opportunities to perform and enact it. However, it is important to note that this constituted just one of the range of overlapping spaces he inhabited. Moving from the semirespectable world of the parliamentary hacks, Finnerty also established himself as a prominent figure in London's radical underworld. Skillfully explored by Iain McCalman, this was a seedy space in which pamphleteers and preachers rubbed shoulders with thieves, pimps, rapists, and blackmailers, and "popular politics intersected with lumpen and professional crime." 57 It was also, like the London press world, a distinctly Irish space; indeed, with exiled radicals arriving in the aftermath of the 1798 rebellion, it was, in some respects, a distinctly United Irish space. ${ }^{58}$ As such, it was also a space on which the authorities attempted to keep a close eye, and Finnerty soon appeared on their radar. Identifying him as "one of the greatest and most bitter enemies of Government," informers noted his movements, producing reports that suggest that he had remained in contact with the dispersed United Irish network that continued to plot and conspire in the aftermath of the '98 rebellion. ${ }^{59}$ One informer had Finnerty traveling to Dublin and participating in preparations for Emmet's Rebellion in the aftermath of Edmund Despard's arrest, while another had him considering a move to Demerara or Suriname. ${ }^{60}$ Given Finnerty's background, the first of these reports was by no means implausible and nor, for that matter, was the second: as recent work has revealed, London was but one site in a wider, transatlantic underworld that encompassed Britain, the West Indies, and North and South America. ${ }^{61}$ Yet, if plausible, these reports appear to have been mistaken, for Finnerty remained in London, and there he busied himself, not with insurrectionary activity, but with electoral politics.

56 “Complaint Against Mr Finnerty, 15 June 1819,” Parliamentary Debates, Commons, 1st ser., vol. 40 (1819), cols. 1182, 1183, 1187.

${ }^{57}$ McCalman, Radical Underworld, 2.

${ }^{58}$ McCalman, "Erin go Bragh," 174; Elliott, Partners in Revolution, 288.

${ }^{59}$ Hone, Cause of Truth, 125.

${ }^{60}$ Bartlett, Revolutionary Dublin, 184n93; Elliott, Partners in Revolution, 296.

${ }^{61}$ Peter Linebaugh and Marcus Rediker, The Many-Headed Hydra: Sailors, Slaves, Commoners, and the Hidden History of the Revolutionary Atlantic (London, 2000), esp. 248-86; Nigel Little, Transoceanic Radical, William Duane: National Identity and Empire, 1760-1835 (London, 2008); James Epstein, Scandal of Colonial Rule: Power and Subversion in the British Atlantic During the Age of Revolution (Cambridge, 2012), 156-83. 
As McCalman has observed, scholars have tended to draw "an overrigid distinction between moral and physical-force activity" and have "failed to notice the swift redeployment of Irish and British revolutionaries into constitutionalist agitations." 62 This process was typified by the group of London radicals who assisted Sir Francis Burdett in his attempts (successful in the first instance, unsuccessful in the latter) to win the seat for Middlesex County in 1802 and 1804. Finnerty was prominent in this group; indeed, in 1804 he produced a pamphlet of Burdett's speeches, replete with a laudatory editorial preface in which he defended the democratic baronet from the "abuse and scurrility" his opposition to corruption and attempts to revive the "old English spirit" had provoked. ${ }^{63}$ In addition to Finnerty, Burdett was assisted by former United Irishmen and United Scotsmen such as Patrick Duffin and Robert Fergusson, and by veterans of the London Corresponding Society and the Society for Constitutional Information, including John Gale Jones and John Frost, the "Jacobin attorney" who had attended the trial of Louis XVI.64 Such men were laden with political baggage, and as McCalman has noted, their presence in Burdett's camp was publicized both in The Times and in the work of the poet and pamphleteer George Huddesford. ${ }^{65}$ While The Times drew attention, in July 1802, to the "formidable opposition threatened by Sir FRANCIS BURDETT, or rather by the Members and Partizans of the ci-dévant Corresponding Societies, to the election of Mr. MAINWARING [the incumbent representative] for Middlesex," Huddesford attacked Burdett's "Jacobin worthies" in The Scum Uppermost When the Middlesex Porridge-Pot Boils Over, his potent satire of the same year, drawing particular attention to the presence among this group of Finnerty, "the assistant of A. O'Connor," who "dressed in green even to his stockings." 66

While it is clear that Burdett's opponents sought to make political capital from his radical associates, the very real contribution that individuals such as Finnerty made to the Burdettite cause should not be overlooked. As both McCalman and J. Ann Hone have detailed, Burdett's cooperation with the radicals was a profitable one. In the late 1790s, they worked together to expose the cruelty to which state prisoners had been subjected in Coldbath Fields Prison, and this, in addition to creating a storm of controversy that forced the government to establish a commission of inquiry, earned Burdett a reputation as a courageous opponent of English Bastilles. Moreover, it fed directly into the Middlesex contest in 1802, for William Mainwaring, Burdett's opponent, was an associate of the Coldbath's governor, Thomas Aris. In short, the radical underworld aided Burdett both overtly, by offering practical electioneering assistance, and covertly, by providing him with a scandal that he brought into the

${ }^{62}$ McCalman, "Erin go Bragh," 170. See also Hone, Cause of Truth, 134-35.

${ }^{63}$ A Full Report of the Speeches of Sir Francis Burdett at the Late Election . . Together with a Selection of Papers Published During the Election; and a Preface, in which a Review is Taken by the Editor of the Conduct, Character and Connections of Sir FRANCIS BURDETT, and also of the Conduct and Character of His Opponents (London, 1804), xxvii-xxviii; John Watkins, Frederic Shoberl, and William Upcott, $A$ Biographical Dictionary of the Living Authors of Great Britain and Ireland (London, 1816), 116.

${ }^{64}$ Hone, Cause of Truth, 134; McCalman, Radical Underworld, 16; Thompson, Making of the English Working Class, 120-21.

${ }^{65}$ McCalman, Radical Underworld, 17.

${ }^{66}$ The Times, 13 July 1802; George Huddesford, The Scum Uppermost When the Middlesex Porridge-Pot Boils Over!! An Heroic Election Ballad with Explanatory Notes. Accompanied with an Admonitionary Nod to a Blind Horse (London, 1802), 6, 10. 
political mainstream, creating a cause célèbre on which he based his successful campaign in 1802. By the following year, his election had been overturned, but his initial victory-a victory that owed much to the endeavors of Finnerty and his associateshad served momentarily to focus popular attention on the issues of reform and corruption. ${ }^{67}$

Metropolitan electoral politics thus provided a space in which the disreputable could combine with the respectable and contribute in a meaningful manner to formal political processes, and Finnerty remained involved in electoral politics in the following years, particularly in Westminster. Alongside William Cobbett, he supported Sheridan between 1806 and 1808, and in 1811 he worked for Samuel Whitbread. ${ }^{68}$ In his own words, he became "a veteran in the management of elections." 69 But again, as with his journalism, it is important to emphasize that this electoral "space" was only one of the number of spaces he inhabited. As well as supporting the electoral campaigns of candidates who were sympathetic to reform, London's radicals also sought, through convivial debating societies, to keep the cause of reform alive at a plebeian level. In these spaces, too, Finnerty was active, playing a prominent role in the establishment of the Robin Hood Society in July $1808 .^{70}$

Finnerty's was not the first Robin Hood Society that had appeared in the capital: a club of the same name, established by at least as early as the 1730s, had flourished in the second half of the eighteenth century, attracting a certain notoriety. ${ }^{71}$ Whether there was any continuity between this earlier Robin Hood Society and that in which Finnerty was involved is unclear, though the fact that John Philpot Curran, who had become Finnerty's friend after serving as his counsel in 1797, had attended the original Robin Hood Society in the 1780s is suggestive. ${ }^{72}$ Whatever the case, the later society soon acquired a notoriety all of its own. In his Satirist, or Monthly Meteor, the conservative muckraker George Manners portrayed it as a "fraternity of pickpockets" and "den of thieves," illustrating his comments with an elaborate cartoon depicting the "Robbing Hood Society" a gathering of drunken ne'er do wells, hell-bent on emptying each other's pockets. ${ }^{73}$ More measured, but still wary, was the assessment

${ }^{67}$ This paragraph draws on Hone, Cause of Truth, 125; McCalman, Radical Underworld, 16-17; and McCalman, "Erin go Bragh," 172-73. See also Thompson, Making of the English Working Class, 19192, 493-94.

${ }^{68}$ Peter Finnerty, History of the Westminster and Middlesex Elections; in the Month of November 1806 (London, 1807), 185-214; Cecil Price, ed., The Letters of Richard Brinsley Sheridan, 3 vols. (Oxford, 1966) 2:292n2 and 301n3; Asquith, "James Perry," 108; Hone, Cause of Truth, 152, 216; Spence, Birth of Romantic Radicalism, 39, 199, 200.

${ }^{69}$ Finnerty, quoted in Asquith, "James Perry," 107.

${ }^{70}$ Hone, Cause of Truth, 147; McCalman, "Erin go Bragh," 174. For a broader examination of London debating societies, see Iain McCalman, "Ultra-Radicalism and Convivial Debating-Clubs in London, 1795-1838," English Historical Review 102, no. 403 (April 1987): 309-33.

${ }^{71}$ The exact date of the original Robin Hood Society's establishment is unknown: a 1764 pamphlet claims that it had first been established as a small "gentleman's club" in 1613, but this appears to be without foundation. London Debating Societies, 1776-1799, ed. Donna T. Andrew (London, 1994), viii; Peter Clark, British Clubs and Societies, 1580-1800: The Origins of an Associational World (Oxford, 2000), 48; Edward Royle, Victorian Infidels: The Origins of the British Secularist Movement, 1791-1866 (Manchester, 1974), 24.

${ }^{72}$ Matthew and Harrison, Oxford Dictionary of National Biography, 14:726.

${ }^{73}$ The Satirist or Monthly Meteor 4 (1809): 1, 3. This was one of a number of cartoons that sought to discredit Finnerty and his associates by criminalizing them. For the "Robbing Hood Society" and loyalist 
of the politician and future silver-fork novelist Robert Plumer Ward. Writing in October 1809, Ward touched upon the society in the following terms:

I cannot help winding up my croaking with the next question before the Robin Hood Society, at which all the mob-leaders preside. It is, whether the jubilee is to be considered as a mark of gratitude to the King for benefits he may have conferred, \&c. \&c., or "a rash and ill-timed experiment upon the feeling of the nation, tending to aggravate the discontent already too prevalent, and spread division throughout the Empire?" The last part is verbatim, as it is placarded all over the streets; and the verdict (no doubt against the King) will be placarded as publicly next week, to work as it may. ${ }^{74}$

Aside from reflecting his own personal misgivings regarding a society where "all the mob-leaders preside," Ward's comments are of interest for the details they offer regarding the Robin Hood Society's attempts to frame the Royal Jubilee as "a rash and ill-timed experiment." The Robin Hood Society sought, in short, to contest the Jubilee, and in so doing it can be seen to bear out Stuart Semmel's recent interpretation of the event as "a hybrid political child of joint loyalist and radical parentage." For Semmel, the Jubilee appears, not as a unifying event, but as a "moment of monarchical commemoration" that provided an opportunity for the expression of both "loyalist devotion" and "radical discontent." "In publicizing an alternative interpretation of the Jubilee as "ill-timed" and "aggravating," the Robin Hood Society was expressing political opposition and contributing to the process by which the meaning of the event was subverted.

While noteworthy in its own right, the Robin Hood Society's subversive engagement with the Jubilee is rendered all the more interesting in light of the fact that Finnerty had been heavily involved in creating the circumstances that had rendered such an event necessary. As Linda Colley has demonstrated, the Jubilee owed much to the anonymous letter-writing campaign of the little-known Welsh widow Rachel Charlotte Biggs, who conceived of the event as a means to counteract the influence of the scandal in which the royal family had become embroiled earlier in the year. ${ }^{76}$ This scandal arose from allegations that Mary Anne Clarke, mistress of the king's brother, the Duke of York, commander-in-chief of the armed forces, had been accepting bribes from officers seeking promotion on the understanding that she would exercise her influence in their favor. The exposure of this state of affairs is generally associated with Clarke's former lover, Colonel Gwyllym Lloyd Wardle, member of Parliament for Okehampton. ${ }^{77}$ However, while it is true that Wardle brought the

cartoons more broadly, see Vic Gatrell, City of Laughter: Sex and Satire in Eighteenth-Century London (New York, 2006), 499-501.

${ }^{74}$ Ward to Lonsdale, 24 October 1809, in Edmund Phipps, Memoirs of the Political and Literary Life of Robert Plumer Ward, 2 vols. (London, 1850), 1:273.

75 Stuart Semmel, "Radicals, Loyalists and the Royal Jubilee of 1809," Journal of British Studies 46, no. 3 (July 2007): 545, 569; Linda Colley, "The Apotheosis of George III: Loyalty, Royalty, and the British Nation, 1760-1820,” Past \& Present 102 (February 1984): 94-129.

${ }^{76}$ Linda Colley, Britons: Forging the Nation, 1707-1837 (London, 2003), 217-18; Colley, "Apotheosis of George III," 112.

${ }^{77}$ For fuller accounts of the Duke of York affair, see Philip Harling, "The Duke of York Affair (1809) and the Complexities of War-Time Patriotism," Historical Journal 39, no. 4 (December 1996): 963-84; Anna Clark, Scandal: The Sexual Politics of the British Constitution (Princeton, 2004), 148-76. 
scandal to a head, raising it in Parliament and sparking an inquiry that captivated British public opinion in the early months of 1809 , the allegations of impropriety had first been aired in a series of caricatures and pamphlets that emerged from London's radical underworld in 1807 and 1808. Of these, the most significant was An Appeal to the Public, and a Farewell Address to the Army (1808), a pamphlet with which Finnerty was closely associated. ${ }^{78}$

Telling the unhappy story of Major Denis Hogan, a frustrated Irish officer repeatedly passed over for promotion, An Appeal to the Public proved to be something of a bestseller. First published in October 1808, it ran through eleven editions by the end of the year, provoking a major controversy with its revelations of bribery and corruption. ${ }^{79}$ The precise nature of Finnerty's contribution to the production of the pamphlet is obscure. He appears, at the very least, to have been involved in publishing it, but many believed him to be nothing less than its author. ${ }^{80}$ In a letter published in The Satirist, George Manners put the matter bluntly: Finnerty was the "author, publisher, and proprietor of Major Hogan's pamphlet."81 Given Manners's hostility toward Finnerty, there are grounds on which to doubt his finger-pointing, but he was by no means alone in identifying Finnerty as the true author of the Hogan pamphlet. Another pamphleteer characterized Finnerty as Hogan's "literary adjutant," noting that the pamphlet was "plentifully sprinkled with that Gentleman's principles," while a third dismissed Hogan as "a mere stalking-horse," insisting that there could be "no doubt" that Finnerty was its author and publisher. ${ }^{82}$ Indeed, so widely acknowledged was Finnerty's role in the affair that the government commenced legal proceedings against him for libeling the Duke of York. These proceedings were eventually dropped, but Finnerty was to remain in the spotlight, and his name was raised several times during the inquiry that followed Wardle's revelations, as sustained attempts were made to ascertain if he had had any dealings with Wardle or Mary Anne Clarke. ${ }^{83}$ Clarke herself was to maintain that Finnerty had been acting in concert with Wardle, and his name appeared, linked with those of the key protagonists, in contemporary cartoons. James Gillray's "Pandora Opening Her Box" is a case in point, depicting Clarke releasing a stench in Parliament from an upturned commode inscribed "opposition stink box," while surrounded by packets of documents, including love letters from Mr. Finnerty and Major Hogan. ${ }^{84}$

${ }^{78}$ Hone, Cause of Truth, 169; McCalman, "Erin go Bragh,” 175; Clark, Scandal, 155-57; Gatrell, City of Laughter, 496-98.

79 Spence, Birth of Romantic Radicalism, 116.

${ }^{80}$ McCalman, "Erin go Bragh," 175.

${ }^{81}$ The Satirist or Monthly Meteor 3 (1808): 500.

${ }^{82}$ A Short English Answer to a Long Irish Story; or, a Key to the Mystery of the Barouche and Bank Notes, Proving Brevet-Major Hogan's Accusations Against His Royal Highness the Duke of York to be Barefaced Calumnies (London 1808), 41, 51; The Democratic Quartetto: Or, Physic for the Fiends; an Excellent Remedy Against the Seditious Hydrophobia, Administered to William Cobbett, Denis Hogan, Peter Finnerty, and Gale Jones; with an Additional Dose for the Independent Whig (London, 1808), 6-7.

83 "Conduct of the Duke of York, 1, 3, 7, 9, and 10 February 1809," Parliamentary Debates, Commons, lst ser., vol. 12 (1809), cols. 287, 289, 329-30, 414-15, 491, 505-06; Phillips, Curran and His Contemporaries, 172-73; Asquith, "James Perry," 211.

${ }^{84}$ Mary Anne Clarke, The Rival Princes; Or, a Faithful Narrative of Facts, Relating to Mrs. M. A. Clarke's Political Acquaintance with Colonel Wardle, Major Dodd, \& c c \& c c \& c . . . Together with a Variety of Authentic and Important Letters, and Curious and Interesting Anecdotes of Several Persons of Political Notoriety, 2 vols. 
Where others might have lain low, hoping that this attention would blow over, Finnerty courted the controversy, responding with bluster and bravado. When George Manners published an article in The Satirist alleging that he had fled London in fear of the consequences of his involvement in the affair, Finnerty publicized his presence in the capital by threatening Manners with a horsewhipping and suing The Satirist's publisher on the grounds that the article had been libelous. Forced to conclude that there was a case to answer, the judge decided in Finnerty's favor, though he did so with evident reluctance, awarding minimal damages and inspiring Manners to pen a mocking verse:

ONE shilling damage and one shilling cost, Is all poor Peter gain'd-not all he lost; For Peter since the judge was so ungracious, To deem his action "friv'lous and vexatious," Must pay his lawyer's bill—or, should he fail, He p'rhaps may rave for freedom - in a jail. Be this reflection then the wretch's hope, His twelve pence damages will buy-a rope. ${ }^{85}$

What mattered, however, was not the size of the damages awarded but the fact that the judge had, in the first instance, been forced to arbitrate on a petty libel case brought by a plaintiff who was himself widely believed to have libeled the Duke of York. Here, in the "hierarchically ordered" space of the court, Finnerty challenged power, enacting his contempt for authority and subverting the law of libel. ${ }^{86}$ Similarly, when his name was mentioned in Parliament, Finnerty submitted a mischievous petition in which he complained "that questions have been put, implying suspicions which may produce an impression injurious to him” and proclaimed himself willing to appear in person and provide "frank, full, and explicit" answers to any questions the House might see fit to ask. ${ }^{87}$ The House declined to call him, perhaps wisely: just what would his "frank, full, and explicit" answers have contained? The point had nevertheless been made: Finnerty was not intimidated by the hostile attentions of Parliament.

By 1809, Finnerty had thus become a well-known figure in metropolitan radical circles and had acquired a degree of notoriety. An established parliamentary reporter and experienced electoral campaigner, he was also a habitué of London's radical underworld, a close-knit community that occupied a "fluid, ambivalent position within the popular political milieu and wider society." 88 In this underworld there was, to quote once more from McCalman, an "intricate overlap between the allegedly

(New York, 1810), 1:80; Draper Hill, ed., The Satirical Etchings of James Gillray (New York, 1976), $140-41$.

${ }^{85}$ John Campbell, Reports of Cases Determined at Nisi Prius, in the Courts of King's Bench and Common pleas, and on the Circuits, from the Sittings After Hilary Term, 49 Geo. III. 1809, to the Sittings Before Easter Term, 51 Geo. III. 1811, Both Inclusive, 2 vols. (London, 1811), 2:72-77; The Satirist or Monthly Meteor 4 (1809): 7-10, 479.

${ }^{86}$ Epstein, "Spatial Practices/Democratic Vistas," 299.

87 "Conduct of the Duke of York, 9 February 1809," Parliamentary Debates, Commons, 1st ser., vol. 12 (1809), col. 441.

${ }^{88}$ McCalman, Radical Underworld, 3. 
separate spheres of 'respectability' and 'roughness'."89 Finnerty epitomized this. A liminal character who straddled the threshold of decency and disrepute, he occupied and moved between a number of distinct spaces, providing a point of contact between high politics and low. As comfortable rubbing shoulders with pickpockets and pimps in plebeian pubs as he was mixing with politicians in Parliament or posturing in the courts, he skillfully exploited the opportunities for political expression that his various metropolitan spaces offered. Indeed, his involvement in bringing about the Duke of York affair, one of the major causes célèbres of the age, highlights the permeability of metropolitan political boundaries and the radical underworld's ability to exploit this permeability in order to disrupt the national political narrative. ${ }^{90} \mathrm{Had}$ his career ended in 1809 , Finnerty would thus merit attention, not merely as an Irish radical whose career post-'98 illustrates Anglo-Irish radical interactions, but as a prominent figure in metropolitan radical circles in his own right, who illustrates the complexity and vitality of wartime radicalism. But Finnerty's career did not end in 1809. If anything, he was to become a more prominent figure still, for in the ensuing years he participated in a controversy that pitted him against another metropolitan Irishman, albeit one from a more exalted social background-Lord Castlereagh.

The controversy in question was not born in the galleries of Parliament, nor in the taverns or debating societies of radical London. Instead, it was born on the muddy shores of the Scheldt estuary, where the British army attempted to capture the Island of Walcheren and open a new front against Napoleon in August 1809. The details of this campaign need not concern us. ${ }^{91}$ It is sufficient to note that the expedition, hampered by political indecision, poor military leadership, and savage outbreaks of malaria and typhoid, was a disaster, and that Finnerty was on hand to report on the scale of the debacle. His presence on the expedition had been facilitated by the controversial naval officer Sir Home Popham, but while he might thus be characterized as an embedded reporter, indulged by the expedition's leadership, the reports he sent to the Morning Chronicle were not calculated to flatter. ${ }^{92}$ Quite the reverse, he wrote frankly about the realities of a campaign during which "an astonishing number" of women and children were killed and disease made "rapid strides" among an ill-equipped expeditionary force. ${ }^{93}$ Moreover, reflecting his

89 Ibid.

${ }^{90} \mathrm{My}$ analysis here is informed by McCalman, "Erin go Bragh," 175.

${ }^{91}$ See, however, T. H. McGuffie, "The Walcheren Expedition and the Walcheren Fever," English Historical Review 62, no. 243 (April 1947): 191-202; Kate Elizabeth Crowe, "The Walcheren Expedition and the New Army Medical Board: A Reconsideration,” English Historical Review 88, no. 349 (October 1973): 770-85; John W. Derry, Castlereagh (London, 1976), 125-30; Martin R. Howard, "Walcheren 1809: A Medical Catastrophe," British Medical Journal 319 (December 1999): 1642-45.

92 Finnerty and Popham met in 1806, in which year Popham had faced a court-martial and Finnerty had assisted him as a shorthand writer. The nature of the invitation Popham subsequently issued is unclear: Finnerty claimed he had been invited to travel with the expedition and write its history, while Popham claimed he had issued the invitation on the understanding that Finnerty would use his influence to keep the name of Lord Chatham, the expedition's commander, out of the papers. Phipps, Memoirs . . of Robert Plumer Ward, 1:396-98; Anne M. Brady and Brian Cleeve, A Biographical Dictionary of Irish Writers (Gigginstown, 1985), 79.

${ }_{93}$ Morning Chronicle, 18 August and 6 September 1809. 
contempt for authority, he excoriated the British leadership, both military and, especially, political: "[T] here can be no doubt of the determination of Ministers to retain this Island, if they can," he observed, in a despatch dated 10 September, "but upon what grounds it rests . . . the more intelligent persons with whom I have conversed here, seem quite unable to discover. . . . Why then will ministers persist in maintaining such a position? Why expose our army to destruction?"94 The overall narrative Finnerty's reports presented might, indeed, be characterized as one of lions led by donkeys, of honest British troops doing their best in trying circumstances, while their "betters," if not proving themselves incapable of making decisions at all, were making decisions based on bad judgment. The result of this was inevitable: Finnerty was ordered home. Convinced that Castlereagh, with whom the expedition was closely associated, had ordered his recall, he returned to Britain in a rage and, in due course, retaliated. In a furious letter published in the Morning Chronicle he lashed out, not only accusing Castlereagh of harboring a personal hatred toward him, but alleging that he had connived in torture when suppressing the United Irish movement in $1798 .{ }^{95}$ Such allegations were intended to provoke, and provoke they did. In his own words, Castlereagh "conceived it incumbent on him, as a public duty to prosecute ... for a libel," and in February 1811 Finnerty found himself once more in court. ${ }^{96}$

In his stimulating analysis of the libel trials that accompanied government attempts to repress radicalism in the postwar period, Kevin Gilmartin has emphasized the way in which British radicals subverted such events. Exploiting the inherent drama of the courtroom, radicals engaged in "dialectical combat," contesting both the meaning and the possibility of libel, and reiterating the very statements that had led to their prosecutions in the first place. As Gilmartin puts it: "A forum for 'defence' became an opportunity for 'offence,' and a presiding judge was forced to test his 'power of preventing' against a defendant's determination to repeat and extend his original provocation." 97 Finnerty's trial typified this process. Rather than attempting a conventional defense, he let judgment go by default and sought to mitigate his libel by presenting affidavits he had collected in Ireland, which served to illustrate its truth. Realizing that Finnerty was, in effect, attempting to turn the trial into an inquest on Castlereagh's actions in Ireland in the aftermath of the 1798 rebellion, adding "fresh libels to those already promulgated" as he did so, the judge, Justice Ellenborough, called a halt to proceedings, offering Finnerty an opportunity to return, a week later, with a more suitable affidavit. ${ }^{98}$ When the proceedings resumed, however, Finnerty reduced them to the level of farce by quibbling with Ellenborough over points of law, and by attempting, once more, to present his affidavits. "Have you, sir," he was asked at one point, "any inoffensive affidavits?" His response captures neatly the tone of the proceedings:

\footnotetext{
${ }^{94}$ Ibid., 13 September 1809.

${ }^{95}$ Ibid., 23 January 1810; Bew, Castlereagh, 247-56.

96 "Mr Brougham's Motion on the State of the Nation, 11 July 1817," Parliamentary Debates, Commons, lst ser., vol. 36 (1817), col. 1420.

${ }^{97}$ Kevin Gilmartin, Print Politics: The Press and Radical Opposition in Early Nineteenth-Century England (Cambridge, 1996), 122. See also Epstein, "Spatial Practices/Democratic Vistas,” 299-300.

98 [Anon.], Case of Peter Finnerty, 4, 22, 24.
} 
None that are inoffensive with regard to Lord Castlereagh, and none that are offensive, as I conceive, with regard to the law or to this court. In consequence of your lordship's dictum, that truth was no justification of a libel, and that therefore I should not be allowed to prove the truth of my letter, I let judgement go by default: I did so, because I understood that on being brought up for judgement, I might produce the truth in mitigation. . . . Since your law was against me, I have deferred to it; but nothing on earth shall induce me to make any submission to Lord Castlereagh. . . . I am ready to prove that Lord Castlereagh does deserve the description which your lordship charges me with applying to him, of being the basest of individuals. And will you then punish me for censuring the conduct of such a man?'99

As was the case in 1809, when he had sued Samuel Tipper, Finnerty was using the courts to create a spectacle and to further perform the contempt for authority that his offense had displayed. But on this occasion he did more than simply frustrate a judge: he succeeded both in publicly besmirching Castlereagh's reputation and in calling into question the credibility of the law itself, highlighting the fact that a statement could be upheld as libelous, even if it could be proved to be true.

As impressive as it was, Finnerty's performance-and performance this undoubtedly was-did nothing to mitigate his offense in the eyes of the court. He was therefore duly sentenced to eighteen months imprisonment in Lincoln Castle. ${ }^{100}$ But this did not mark the end of the controversy. "As long as word of a trial got out, in spoken and printed versions," Gilmartin has noted, "even a guilty verdict would not be the last word."101 Finnerty's trial typified this process also. Not only was his audacious performance recorded for posterity in a published account of the proceedings, but his affidavits came back to haunt Castlereagh in 1817, when Henry Grey Bennet, an ally of Henry Brougham, presented them in Parliament during a debate on the state of the nation. ${ }^{102}$ In the short term, moreover, the controversy was kept alive by the adoption of Finnerty's cause by radicals and reformers. ${ }^{103}$ This was most notable in London, where Sir Francis Burdett chaired a sizable meeting of support at the Crown and Anchor Tavern, but it was not limited to the capital: subscriptions for Finnerty's support were established by reformers in Liverpool, Belfast, and Dublin, while in Oxford Percy Bysshe Shelley, then a little-known undergraduate, sought to raise money for Finnerty's support by publishing his Poetical Essay on the Existing State of Things (1811). ${ }^{104}$

For his part, moreover, Finnerty helped keep the controversy alive by petitioning Parliament to complain about the conditions of his imprisonment. In so doing, he

99 Ibid., 30.

100 Ibid., 61.

${ }^{101}$ Gilmartin, Print Politics, 124.

102 "Mr Brougham's Motion on the State of the Nation, 11 July 1817," Parliamentary Debates, Commons, lst ser., vol. 36 (1817), cols. 1416, 1417, 1420, 1444.

${ }^{103}$ McCalman, "Erin go Bragh,” 178.

${ }^{104}$ Morning Chronicle, 15 March 1811; Belfast Monthly Magazine 6 (1811): 149; W. J. Fitzpatrick, Secret Service Under Pitt (London, 1892), 200; Charlotte Campbell Bury, Diary Illustrative of the Times of George the Fourth, Interspersed with Original Letters from the Late Queen Caroline, and from Various Other Distinguished Persons, 2 vols. (Paris, 1838), 1:38; The Academy, 19 December 1874; Asquith, "James Perry," 290; Richard Holmes, Shelley—The Pursuit (London, 1975), 51-52; Times Literary Supplement, 12 July 2006; Jonathan Jeffrey Wright, The "Natural Leaders" and Their World: Politics, Culture and Society in Belfast, c. 1801-1832 (Liverpool, 2012), 75-78. 
attacked the prison governor, alleging that he had "set apart 13 rooms for his own use, while his family consists of only three persons." 105 This provoked a flurry of debate and an irate counterpetition in which the governor accused Finnerty of attempting to bribe a turnkey "to permit him to be criminally connected with a female convict." 106 None of this was particularly edifying, but as was doubtless intended, it served to keep Finnerty's name-and, by extension, Castlereagh's before the public mind. In so doing, it might also be said to have undermined and subverted that most prominent site of political authority-Parliament itself.

At first sight far-fetched, this reading is lent credence both by the content of Finnerty's petition to parliament-which brazenly reiterated his libel on Castlereaghand by an intriguing speech he had earlier delivered to the Dublin Catholic Committee, while in Ireland collecting the affidavits he later attempted to present in court. Urging the Catholic Committee to petition Parliament for emancipation as often as the opportunity presented itself, he reasoned that unsuccessful petitions were of use on the grounds that "every thing which happens in the House of Commons is looked at by the people" and "every rejection of your petition facilitates the downfall of those Ministers, who are irreconcilable enemies, by increasing the odium which attaches to their conduct and principles." 107 Taken alongside Finnerty's spreading of misinformation relating to Wilberforce's "potato speech," his parliamentary petitions in 1809, and his quarrel with a parliamentary officer in 1819, this speech appears highly significant. Indeed, it seems fair to conclude that Finnerty not only appreciated that Parliament was susceptible to subversion but also succeeded, on a number of occasions, in capitalizing upon this susceptibility. Finnerty was not merely a parliamentary journalist but was, in a hitherto unrecognized way, a parliamentary actor.

Having served his sentence, Finnerty was released from Lincoln Castle in 1813, whereupon he returned to work for the Morning Chronicle, his celebrity secured. In a passage that foregrounds, once more, his ability to exploit the permeability of metropolitan political boundaries, one associate later recalled that Finnerty became, in Parliament, "a species of privileged character." Indulged by public figures, he was often to be seen "button-holding the leading men of the Whig and popular parties in the lobby in the most familiar manner." 108 Inevitably, encounters with Castlereagh occurred. One anecdote has Finnerty commenting after such a meeting: "My opinion is he will cut his own throat one of these days-he will!"109 When Castlereagh did cut his own throat in August 1822, just weeks after Finnerty's

\footnotetext{
105 "Petition of Mr. Finnerty Complaining of his Treatment in Lincoln Castle, 21 June 1811," Parliamentary Debates, Commons, lst ser., vol. 20 (1811), col. 727.

106 "Petition of the Keeper of Lincoln Gaol Respecting Mr. Finnerty, 1 July 1811," Parliamentary Debates, Commons, lst ser., vol. 20 (1811), col. 775. Later in the century, Curran's biographer noted in quaintly Victorian terms that Finnerty was "ever amatory" an observation that suggests the governor's allegation may well have been true. Phillips, Curran and His Contemporaries, 174.

${ }^{107}$ [Catholic Committee], Proceedings of the Catholic Committee, as Taken from Their Accredited Papers (Dublin, 1811), unpaginated, proceedings for 2 November 1810.

${ }^{108}$ Fraser's Magazine 65 (1862): 172.

109 Cyrus Redding, Fifty Years' Recollections, Literary and Personal, with Observations on Men and Things, 3 vols. (London, 1858), 2:176.
} 
own death, this story was recalled, but it may well have been apocryphal. Another account tells of a meeting during which Castlereagh bowed politely, as was his custom, and Finnerty observed that, though he hated "his policy and politics," he was "one of the most gentlemanly men in the House of Commons." Conversely, a third has Finnerty informing Castlereagh that he hoped "to live to see the day" when he cut his throat. ${ }^{110}$ Whatever the truth of these stories, they highlight the intimate and close-knit nature of late Georgian Westminster, a milieu that brought pressmen and politicians together face-to-face and in which Finnerty had emerged as a prominent personality.

Equally prominent in this close-knit milieu was William Hazlitt, whose acquaintance Finnerty made in the years following his release from prison. Hazlitt's most recent biographer, Duncan Wu, has cast Finnerty in the role of a "cunning," harddrinking, and influential elder hack. Indeed, he places him on stage on the fateful day in April 1813 when Hazlitt, having sat through a stultifying speech by Richard Wellesley, brother of the Duke of Wellington, retired to the Cider Cellars and drafted an enraged commentary that effectively signaled the birth of the modern political sketch. However, while intriguing, this is purely speculative: in his endnotes, Wu concedes that "Finnerty's role in this affair is inference." 111 What might be said, given his own contempt for authority and the pretensions of politicians, is that Finnerty would have thoroughly approved of Hazlitt's sketch, which mocked Wellesley's long-winded speeches as "prodigies of physical vigour and intellectual imbecility." 112 But regardless of Finnerty's influence on this occasion, the pair's relationship remains of interest, because the writings of Hazlitt, the most perspicacious essayist of the age, offer some of the sharpest glimpses of Finnerty's personality. It was Hazlitt, for instance, who noted the limits of his irreverent sense of humor: "I remember my old friend Peter Finnerty laughing very heartily at something I had written about the Scotch," Hazlitt noted in his memoirs, "but it was followed up by a sketch of the Irish, on which he closed the book, looked grave, and said he disapproved entirely of all national reflections." 113 Likewise, several years after Finnerty's death, Hazlitt objectively enumerated his flaws in a vignette that remains vivid to this day. "FINNERTY was coarse, even gross in his general habits," he wrote, "of a large and awkward frame; had a ludicrous cast in one eye that heightened his rich humour; and was possessed of a peculiarly mellifluous brogue, which he appeared to cultivate as a mark of distinction. . . . [H]e loved Ireland to the last, and would overwhelm any man with a torrent of Billingsgate who would speak disrespectfully of the sod." He was "a rough satirist-spared no man's feelings - heeded no man's antipathies_-and took more pleasure in provoking his enemies than conciliating his friends. He was essentially a man for the mob-his element was popular tumult-he had no sense of conventional refinementsdespised etiquette-abhorred negus, and gloried in whiskey-punch." 114

\footnotetext{
${ }^{110}$ Fraser's Magazine 65 (1862): 173; Grant, Newspaper Press, 2:230.

${ }^{111} \mathrm{Wu}$, William Hazlitt, 145, 150, 164, 472nl1.

${ }^{112}$ William Hazlitt, "The Marquess Wellesley," in Wu, New Writings, 2:432.

113 William Carew Hazlitt, ed., Memoirs of William Hazlitt: With Portions of His Correspondence, 2 vols. (London, 1867), 2:293.

${ }^{114}$ Hazlitt, "Peter Finnerty," 224-26.
} 
Another figure whose acquaintance Finnerty made at this time, and whose later reminiscences shed light on his character, was the weaver-radical Samuel Bamford. The two met in Oldham, in September 1819, Finnerty having been sent there to report on the inquest into the death, from injuries sustained at the Peterloo demonstration, of John Lees. When expelled from the inquest, along with a number of other metropolitan journalists, Finnerty sought, with "much ease, and perfect self-possession," to procure the notes Bamford had been permitted to take in preparation for his own forthcoming trial for inciting riot. Although initially reluctant, Bamford eventually agreed to provide "notes and verbal communications" relating to the trial, and Finnerty, seemingly impressed, suggested that he could assist him in securing employment at the Morning Chronicle. Thus, shortly after Finnerty's departure from Oldham, Bamford followed, joining him at Wolseley Bridge, the Staffordshire home of the aristocratic reformer Sir Charles Wolseley. From there, the two traveled on to London, with Finnerty proving himself to be a "troublesome, querulous, but sometimes amusing companion," not least when he realized a silk umbrella he had purchased in Manchester for the sum of two pounds had been lost. "He went into a passion, and stormed with all the wordiness and gesticulation for which his countrymen are remarkable," Bamford later recalled. "[W] hen we parted for the night, he was in very bad humour.” The pair's relationship survived the lost umbrella, but not for long. Once in London, Finnerty quickly forgot about his erstwhile companion: the promised position at the Morning Chronicle never materialized, and when Bamford visited him at his home, Finnerty dealt with him perfunctorily, leaving him to reflect on the "sudden termination" of their friendship. ${ }^{115}$

Had he later read Hazlitt's reminiscences, Bamford might well have agreed that Finnerty lacked a sense of "conventional refinements" and "spared no man's feelings." Yet while they corroborate Hazlitt's account in some respects, Bamford's recollections also complicate his portrayal of Finnerty as a "man for the mob" who "despised etiquette." That Finnerty was a rough-edged character is not in doubt. As has been demonstrated, he was a hard-drinking and, at times, disreputable, journalist, whose political engagement was underpinned by a vigorous contempt for authority. But this contempt for authority prevented him neither from forging relationships with those of a more exalted social station nor from adopting a superior, patrician manner. Thus, when he arrived at the home of Sir Charles Wolseley, Bamford found Finnerty "quite comfortably domiciled" and "somewhat changed in his manner." He had "become quite condescending," and Bamford was left with the impression that his place was "in the housekeeper's room," while Finnerty's was "in the parlour with Sir Charles." 116 It is, of course, possible that Bamford's recollections were colored by Finnerty's neglect and dismissal of him in London. Yet when placed alongside the relationships he is known to have sustained with such genteel-or, at any rate, nonplebeian-figures as Arthur O'Connor, John Philpot Curran, Sir Francis Burdett, and Richard Brinsley Sheridan, Bamford's comments point to the flexibility of Finnerty's persona. A "rough satirist" he may have been, but Finnerty was not simply "a man for the mob." He may have taken pleasure

\footnotetext{
${ }^{115}$ Henry Dunckley, ed., Bamford's Passages in the Life of a Radical and Early Days in Two Volumes, 2 vols. (London, 1905) 2:202, 203, 206-07, 208, 216-17.

116 Ibid., 2:204.
} 
in provoking his enemies, may even have "despised etiquette," but he was more than capable of moving among the refined when it suited him to do so.

Leaving aside the insights they offer regarding Finnerty's social agility, Bamford's reminiscences are of further interest in placing Finnerty in the vicinity of Manchester in the aftermath of Peterloo. Some viewed this as suspicious: while at Wolseley Bridge, Bamford overheard "two respectable back-biters" making what he described as "too free allusions to the parts which Sir Charles Wolseley and Mr. Finnerty had been acting in the Manchester affair, and to their political conduct generally." 117 The implication here is that Finnerty was believed by some to have been involved in the agitation that had taken place in the run-up to the ill-fated demonstration at St. Peter's Field. Whether this was the case or not is unknown. Wolseley is, however, known to have been involved, and it can certainly be said that Finnerty remained involved in radical politics in the later 1810s. ${ }^{118}$ When, in 1817, the onetime United Irish informer Thomas Reynolds was summoned to serve on the County Middlesex grand jury that presented an indictment of high treason against James Watson and the organizers of the Spa Fields meeting, Finnerty exposed his past, informing the parliamentarian Montague Matthew, member of Parliament for Tipperary, who revealed the fact to dramatic effect in the House of Commons. ${ }^{119}$ Here, again, we see him influencing affairs in Parliament. Similarly, during Watson's trial, he used the columns of the Morning Chronicle to call into question the motivation of the government witness Vincent George Dowling, linking him to another witness, the informer John Castle. ${ }^{120}$ Such actions not only served to challenge the legitimacy of the trial of the Spa Fields rioters but also formed part of a larger radical campaign, culminating with the unmasking of the notorious agent provocateur "Oliver," whereby the government's recourse to spies and informers was exposed, undermined, and delegitimized. ${ }^{121}$

As had been the case during the Duke of York affair and, earlier still, during the Middlesex elections of 1802 and 1804, it is thus possible to identify Finnerty as a prominent player in British radical politics in the late 1810s. Given this, he might be expected to have been involved in the controversy that arose when George IV sought to divorce his long-estranged wife, Caroline of Brunswick, in the autumn of 1820 . However, while metropolitan radicals made much of this episode, springing to the defense of the queen and portraying her as a wronged woman, suffering at the hands of a corrupt and self-interested establishment, Finnerty is nowhere to

117 Ibid., 2:203-04.

118 Donald Read, Peterloo: The Massacre and Its Background (Manchester, 1958), 39, 110, 113, 144

119 Morning Chronicle, 15 May 1822; "Irish Insurrection Act Continuance Bill, 13 June 1817," Parliamentary Debates, Commons, 1st ser., vol. 36 (1817), col. 971; Thomas Reynolds, The Life of Thomas Reynolds, Esq., Formerly of Kilkea Castle, in the County of Kildare, 2 vols. (London, 1838), 2:112-15.

${ }^{120}$ Morning Chronicle, 18, 19, and 20 June 1817. For the aftermath of this affair, which saw Dowling assault Finnerty with a horsewhip, see The Times, 21 June and 3 July 1817, and Dublin Evening Post, 26 June and 8 and 10 July 1817.

${ }^{121}$ Hone, Cause of Truth, 328-29; Bernard Porter, Plots and Paranoia: A History of Political Espionage in Britain, 1790-1988 (London, 1989), 49-64. For contrasting interpretations of "Oliver," see A. F. Fremantle, "The Truth about Oliver the Spy," English Historical Review 47, no. 188 (October 1932): 606-16; Thompson, Making of the English Working Class, 711-36. 
be seen. ${ }^{122}$ In April 1819 Cobbett raised Finnerty's name in his Weekly Political Register, addressing him in an open letter on the subject of Borough Banks. ${ }^{123}$ Likewise, in June 1819 he came to public attention, as discussed above, when he was called before the bar of the House of Commons and reprimanded for abusing a parliamentary officer, but thereafter Finnerty recedes from notice. Most likely, this was a consequence of his fondness for whiskey-punch, a fondness that seems to have increased toward the end of his life. Certainly, those who encountered him in his later years were struck by his drunkenness and the growing frustrations of his editor, James Perry. ${ }^{124}$ One associate recalled a dinner with Perry during which Finnerty arrived in a state of "brutal intoxication." He was duly ejected, following which a letter arrived proposing a duel. Perry returned the letter without response, ruefully observing that he would "hear no more of him until he wants money."125 Given such encounters, Perry could be forgiven had he breathed a sigh of relief upon hearing of Finnerty's death in May 1822. But he did not let the passing of this "rough satirist" go unnoticed. In a fitting tribute, he marked it with a lengthy obituary that alluded to Finnerty's politics of contempt, identifying as his "leading characteristic" the "instinctive hatred of oppression, whatever shape it assumed, or by whatever influence it was attempted to be enforced."126

A onetime Dublin pressman, Finnerty played a prominent role in the political culture of late Georgian Britain. As a journalist and agitator, he helped shape and publicize controversies that provided radicals and reformers with valuable opportunities for political expression, and when challenged by the authorities, as in 1811, he proved adept at subverting the institutions of the state. At a time when the provisions of the Treasonable and Seditious Practices Act expressly forbade the articulation, either in speech or print, of "words or sentences" calculated to "excite or stir up the people to hatred or contempt ... of the Government and Constitution," Finnerty performed contempt, created spectacle, and challenged authority in both the courts and Parliament itself. ${ }^{127}$ Thus his career reflects the variety and creativity of the British radicals' response to attempts at suppression, and it reinforces the assertion of Epstein and Karr that the "embodied practices of radicalism, its style and modes of theatricality," constitute an important area of investigation in their

\footnotetext{
${ }^{122}$ Thomas W. Laquer, "The Queen Caroline Affair: Politics as Art in the Reign of George IV," Journal of Modern History 54, no. 3 (September 1982): 417-66. See also Anna Clark, "Queen Caroline and the Sexual Politics of Popular Culture in London, 1820," Representations 31 (Summer 1990): 47-68; Tamara L. Hunt, "Morality and Monarchy in the Queen Caroline Affair," Albion 23, no. 4 (Winter 1991): 697-722; Dror Wahrman, "'Middle-Class' Domesticity Goes Public: Gender, Class, and Politics from Queen Caroline to Queen Victoria," Journal of British Studies 32, no. 4 (October 1993): 396432; Jonathan Fulcher, "The Loyalist Response to the Queen Caroline Agitations," Journal of British Studies 34, no. 4 (October 1995): 481-502; and Clark, Scandal, 177-207.

${ }^{123}$ Cobbett's Weekly Political Register, 3 April 1819. I am grateful to Carl Griffin for sharing this reference.

${ }^{124}$ Frederick Knight Hunt, The Fourth Estate: Contributions Towards a History of Newspapers, and of the Liberty of the Press, 2 vols. (London, 1850), 2:279.

125 Gordon, Personal Memoirs, 1:298-300.

126 Morning Chronicle, 15 May 1822.

127 A. Aspinall, David Charles Douglas, and Ernest Anthony Smith, eds., English Historical Documents, 1783-1832 (London, 1996), 382.
} 
own right. ${ }^{128}$ But perhaps above all, his career highlights the role, hitherto overlooked, of the nonelected parliamentary actor.

Finnerty's actions in Parliament in June 1819, when he ignored an instruction to stop taking notes, were not simply the actions of an intemperate "man for the mob." Rather, they were those of a canny radical agitator who was conscious that Parliament, no less than the courts, could be undermined and delegitimized if its authority was treated with contempt. Likewise, when placed within the broader context of his career, the petitions he submitted to Parliament during the Duke of York affair and in the aftermath of his imprisonment in 1811 assume the appearance of calculated, strategic interventions-parliamentary intrusions that reiterated libels and kept controversy before the public eye. By trade Finnerty might have been a reporter, but it was through his actions as well as his written words that he shaped parliamentary narratives.

In short, then, Finnerty is a figure who merits attention in his own right. But more broadly, his life story attests to the ongoing interaction of English and Irish radicals in the years immediately following the decline of the United Irish movement. Indeed, it suggests that those more well-known periods of Anglo-Irish radical interaction, the 1790 s and the later 1830s, form part of a longer, continuous story. To be sure, Finnerty might have been one of the more remarkable characters in this story, but he was certainly not unique. "In the ten years preceding the Chartist Movement," Dorothy Thompson noted, as long ago as 1982, "there is clear evidence of the presence of Irishmen as metropolitan radical journalists, and as important figures in the provincial trade societies, particularly in the textile industries." 129 If the life of Peter Finnerty suggests anything, it is that these individuals-representatives of an important and long-running Anglo-Irish radical tradition-deserve more attention than they have, in recent years, received.

${ }^{128}$ Epstein and Karr, "Playing at Revolution," 496.

129 Thompson, "Ireland and the Irish in English Radicalism," 132-33. 